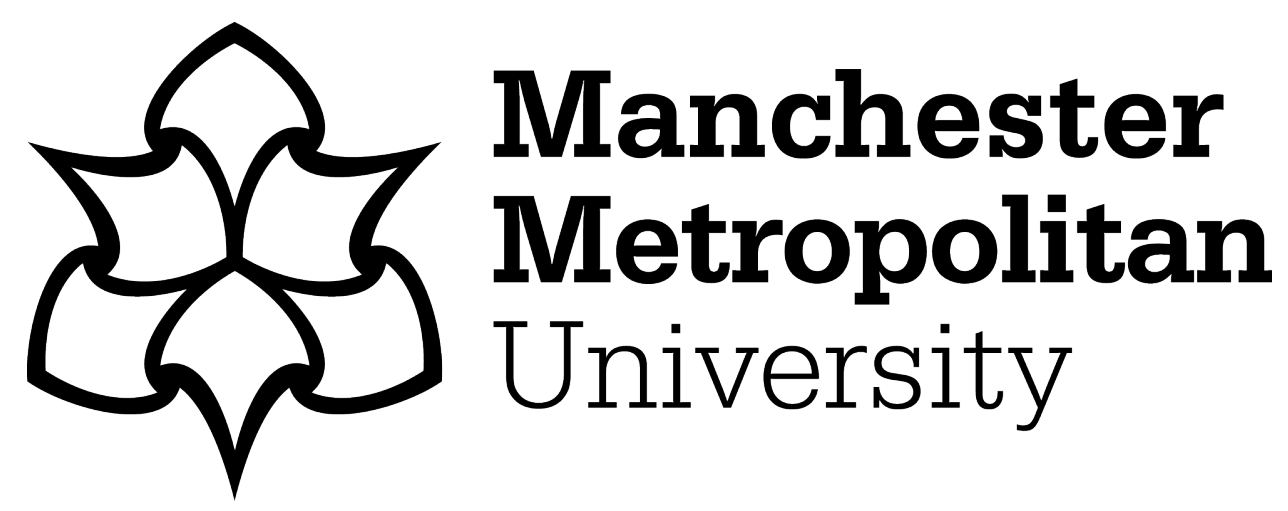

Christie, Fiona ORCID logoORCID: https://orcid.org/0000-0003-1384-3683, Rattenbury, james ORCID logoORCID: https://orcid.org/0000-0001-69390826 and Creaby, Fiona ORCID logoORCID: https://orcid.org/0000-00033986-2639 (2020) The space of authoring in constructing student and graduate career identities. In: Social theory and the politics of higher education: critical perspectives on institutional research. Bloomsbury. ISBN 9781350141551

Downloaded from: https://e-space.mmu.ac.uk/625737/

Version: Accepted Version

Publisher: Bloomsbury

Please cite the published version 


\title{
The space of authoring in constructing student and graduate career identities
}

\author{
Authors - Fiona Christie, James Rattenbury, Fiona Creaby
}

\section{Introduction}

This chapter illustrates the application of Figured Worlds ${ }^{1}$ theory (Holland, Lachicotte, Skinner, \& Cain, 1998) in exploring student and graduate identities. It argues that Figured Worlds offers a novel lens to explore contemporary identity in a context in which a competitive graduate labour market puts added pressure on individuals' sense of who they are and want to become. Figured Worlds is a sociocultural theory that seeks to create a model for analysis and interpretation of social worlds that engages with how individuals and collectives respond to their cultural and material circumstances. Although the theory has been used within the social sciences for nearly twenty years, it has had limited reach amongst researchers of higher education. In their seminal book, Identity and Agency in Cultural Worlds, Holland et al. (1998) address a central paradox that humans are products of context and yet producers of remarkable improvisation. Predominantly, they hybridise Bakhtinian, Bourdieusian and Vygotskian ideas to argue for a social perspective that frames identity as a dialogical performance of multiple selves, continually developed through social engagement. We argue that the theory's blend of the traditions of Soviet philosophy and social psychology, American empirical anthropology and French sociology offers a valuable lens for analysis of individual subjectivities in contemporary contexts in which neoliberal ideas appear to have hegemonic influence over society, the economy as well as individual psychology. Such hybrid theory can serve to make us pause and reflect upon how we make sense of and resist social worlds, in which engines of control

\footnotetext{
${ }^{1}$ Figured Worlds in upper case refers to the theory as a whole; figured worlds in lower case is one of four constructs within the whole theory.
} 
exist in dispersed ways. Notably some of Holland and her co-authors' writing is being recently republished, which is an indicator of its renewed appeal (Holland and Lave, 2019).

Figured Worlds is a social practice theory, and it places emphasis on activity and the interaction of actors in specific contexts. It shares characteristics with social theory and theorists, e.g., Archer (2007) who explore issues of the reflective self, and the role of structure and agency for individuals and collectives. In our view, a key marker of difference in Figured Worlds theory is its anthropological focus on culture in its micro-sociological analysis. It also gives priority to the relationship between theory and method. Perhaps owing to their American scholarly heritage, Holland et al. (1998) present theory using empirical data, resonating with the Chicago School's theoretically informed empiricism and symbolic interactionist approach (Blumer, 1986; Mead, 1934) which sought to uncover how individuals confer meaning on themselves, rather than how it is attributed by others.

We argue that there are implications for researching higher education based on application of the theory. A consideration of how Figured Worlds' tools are applied across different students/ graduates offers a way to highlight and discuss how identity develops and how this can support individuals when constructing meaning and developing agency in uncertain circumstances. It allows for a critical review of contemporary higher education contexts, arguing that individual subjectivities are ignored when concepts such as the 'Student Voice' are co-opted as part of extended feedback collection, rather than exploring the complexity of student and graduate identities, and the normal multiplicity of voices therein. Particular strengths of the theory lie in tools such as a consideration of 'voice' and how people orchestrate dialogically competing 'voices' and 'narratives' ('heteroglossia') (Holland et al., 1998, p.170). Notions of 'multi-voicedness' or 'heteroglossia' allow for a focus on dynamic individual subjectivities, which serve to firmly distance Holland et al.'s approach (1998, p. 45) from a classic Bourdieusian analysis, which argues that enduring habitus transformation can only occur across generations. We acknowledge that newer scholars of Bourdieu would take issue with their depiction of Bourdieusian theory and defend his work, arguing that it does allow for examples of shorter-term habitus evolution (e.g., Choudry and Williams, 2016; Ingram and Abrahams, 2015). 
However, we contend that Figured Worlds allows for a deeper exploration of how individuals/collectives make their own meaning, giving scope for small transformations.

Qualitative data from one of the authors' research with recent graduates in the north of England (Christie, 2018) will illustrate the theory's application. The data presented will focus on imagined ideas of being a graduate and the career possibilities that may follow. Two exemplars are used to illustrate Figured Worlds' thinking tools. Presentation of data follows an in-depth analysis, giving close attention to interview data, which has been the predominant way that Figured Worlds has been applied. The integration of the theory's tools with contemporary literature about careers and employability informs the analysis outlined in this chapter. Figured Worlds broadly adopts a textual/ narrative analytical approach, with priority given to elements of language, e.g., the imagery, tropes, repetitions, and new words that are used by participants.

\section{Figured Worlds theory - underlying principles}

Holland et al. (1998) synthesise ideas from a range of 20th century thinkers. From Bourdieu (1977a, 1977b) they reshape notions of habitus into what they call 'history-in-person' (Holland and Lave, 2001), i.e., those embodied dispositions and characteristics which constrain people but may also give scope and allow for improvisation. They also draw on ideas of the field, which they call 'figured worlds' (1998, p.41), where a set of structured practices and objective relations exist and position people, which Holland et al. depict figuratively, as well as materially. They invoke Bourdieu's (1977a, 1977b) depiction of agency, which involves strategic improvisation within the limited choices that are available within a field, exploring in some detail what needs to be in place for such agency to be enacted.

From Vygotsky $(1978,1986)$ and Leont'ev $(1978)$ they adopt a focus on semiotic mediation in activity, and the conception of a self that develops within a 'zone of proximal development' (Holland et al., 1998, p.272) and is associated with 'scaffolding' (p.83) that allows for growth. Their 'figured worlds' (p. 41), share this focus on the symbolic. Building upon Bourdieu's (1977a, 1977b) emphasis on power in the field through objective agents and institutions, the 'figures' (Holland et al., 
1998, p.51) that appear in the 'figured worlds' of Holland et al. may be material/embodied subjects and/or objects but are also likely to be mediated semiotically through cultural models and signs. Such signs that are framed linguistically can enter the psyche and become incorporated into one's 'historyin-person' (p. 65), which can contribute to future reflection, improvisation and action in a process they call 'symbolic bootstrapping' (p.267). Such signs, symbols, or mediating devices/tools may include specific words, metaphors or phrases, but also emblematic 'narratives' (p.53). They describe such signs as 'identity tools' (p. 41). We argue, for example, that words or phrases such as 'the graduate' or 'the unemployed graduate' have both material and symbolic meaning. Graduation itself is steeped in symbols, e.g., caps, gowns, certificates and ceremony, all acting as markers of the cultural importance of this life event. Signs may be rooted in use of figurative language, but arguably can also be traced in how graduates depict their situation in 'narrative' terms, drawing on discourses and cultural models.

Extending this use of the symbolic, from Bakhtin (1981, 1986), Holland et al. (1998) adopt an emphasis on the uses of language. They adopt the notion of 'dialogism' (p. 169) and that individual speech and action are always in dialogue and responsive to others and context. Thus, people 'selfauthor' (p.170) their identities using the cultural tools that their historical context gives them, speaking in different genres as they generate 'narratives' (p.53) about themselves. Arguably, dominant discourses of graduate employability and careers have certain 'narratives' which underscore how individuals construct meaning (Christie, 2018; Pryor and Bright, 2008). Major 'narratives' (or what they also refer to as 'standard plots') include the 'narrative' of mobility and transformation ('rags to riches'), which is associated with the 'public story of higher education' (Brooks and Waters, 2017; Finn, 2015; Loveday, 2015). Additionally the 'narrative' of adversity ('overcoming the monster') is associated with neoliberal ideas of 'grit' (Duckworth, 2016) and more recently 'resilience' (Burke and Scurry, 2019). In addition, we as authors have suggested elsewhere four 'voices' that capture societal perspectives on careers (Christie, 2019). The idealistic 'voice' resonates with a values-based and subjective definition of career success exemplified by the protean career orientation (Hall, 2004). The tactical 'voice' evokes a more competitive and strategic approach (e.g., 
D'Alessandro, 2008). The self-critical 'voice' reflects a belief in meritocracy, so lack of success is based on individual shortcomings (Moreau and Leathwood, 2006); and finally, the context-critical 'voice' can stem from both a view of higher education as a disappointed consumer and/or an awareness of a degraded labour market for graduates (Standing, 2014; Tomlinson, 2014).

In homage to Bakhtin, they refer to the 'space of authoring' (1998, p.170) that is complementary to Vygotsky's 'zone of proximal development'. They also draw together Bakhtin's notion of the 'carnivalesque' and Vygotsky's notion of 'serious play'(p.272) to explore how the 'space of authoring' may offer scope for challenging rules, and argue that individuals may create new ways of thinking and acting, by the orchestration of the different 'voices', 'narratives' and discourses available to them within 'figured worlds'.

Holland et al. (1998) define 'identity in practice', which is the core object they seek to illuminate in their theory:

We take identity to be a central means by which selves, and the sets of actions they organise, form and re-form over personal lifetimes and in the histories of social collectivities... Identity is one way of naming the dense interconnections between the intimate and public venues of social practice... Practiced identities are constructs that can be referenced to several contexts of activity. (Holland et al., 1998, pp. 270-271)

They go on to summarise four constructs (p.271-272) that can be used by those using a Figured Worlds lens. An understanding of these constructs is pivotal in considering what improvisation an individual may make within a field or figured world.

1. figured worlds - the field populated with embodied and symbolic figures, and cultural models.

2. positionality - the position held in a field linked to power, status and rank.

3. space of authoring - the resources available to author self and narratives utilised. 
4. world making - the imagining of a different social positioning and structure, through the orchestration of existing cultural resources/voices.

In this chapter, we will focus primarily on the constructs of 'space of authoring' and 'figured worlds', and mainly explore the thinking tool of 'figured identities'(p.141), and how these develop through the use of different 'voices' and 'narratives'.

\section{Figured identities - on being and becoming a graduate}

'Figures' that graduates author themselves in relation to, can represent the idealised 'could be' or 'should be' models that individuals measure themselves against. Holland et al. (1998, p. 51) use examples of 'figures' within the domestic political world of Nepali women, e.g., a good woman or a good daughter. Others have applied Holland et al.'s theoretical notion of 'figures', e.g., in in relation to competing 'figures' of being a 'caring' or 'competent' doctor (Bennett, Solomon, Bergin, Horgan, and Dornan, 2017). In this tradition, it is possible to argue that 'figures' associated with being a graduate are embedded in cultural ideas of what it represents and how this relates to having a career that befits a graduate. A notion of what 'could be' or 'should be' influences how individuals explain their situation and what language they use. Such 'figures' are associated with the identity-making that graduates invest in and the liminality that is commonplace (Holmes, 2015) for recent graduates' identity formation. This is called 'figured identity'.

The rite of passage of becoming a graduate has a long history, e.g. evocatively illustrated in the 1960s film The Graduate (director, Mike Nichols, 1967), in which the lead character has just completed his degree and returns home to a party celebrating his graduation at his parents' house, uncomfortable as his parents deliver accolades and neighbourhood friends ask him about his future plans. Despite the lead character's own ambivalence to his homecoming, such a depiction epitomises the 'figure' of a graduate as one of expectancy and hope, on the brink of a new life. This depiction is not just a private one but is also social; collectively graduates and their destinies act as a touchstone for what the future may be like for us all. Much of society invests considerable hope in graduates; the word itself invokes a certain status that is not accorded to other leavers of cycles of education/training 
such as school leavers or completing apprentices. The co-opting of the status of the word graduate has been attempted in other contexts, e.g., in the enactment of graduation ceremonies for nursery children. More recent depictions of the 'figure' of the graduate in contemporary literature are increasingly ambivalent (e.g., Bissett, 2011; Killeen, 2015), but retain hope and expectation at their core. Even hip-hop musicians write about what it is to be a graduate or conversely to be a 'college drop-out' illustrating the enduring cultural resonance of becoming or not becoming a university graduate (e.g., West, 2004).

Labour market literature substantiates the ambivalence of such cultural evocations, illustrating how the definition of a graduate job has evolved (Elias and Purcell, 2013), while the spectre of graduate unemployment/underemployment attracts media attention and fears of both economic and societal failure (CIPD, 2015; Tholen, 2014). Within this context of engrained but uncertain notions of what a graduate is, government-led employability policy drivers have contributed to defined notions of what being a successful graduate is as measured by positive outcomes in the guise of further study and graduate level employment (HESA, 2016). Universities focus attention on skills, attributes, scholarship, citizenship (Barrie, 2012; Dacre Pool and Sewell, 2007; Yorke, 2006) in outlining what characterises a graduate. Holmes (2015) has led criticism of prevailing ideas of measuring graduateness in terms of skills/attributes, preferring to foreground a graduate identity approach; he argues that for individuals, it can be an uncomfortable journey to feel worthy to call themselves a graduate and being in a work/career situation that allows them to do this. Normative implications surrounding public policy and graduate career prospects are increasing as it is suggested that funding for courses should follow likelihood of success in the labour market (Augar, 2019).

'Figured identities' intersect with 'positional or relational identities', the latter giving more emphasis to issues of positioning, power, and inequality that may impact on the ability to claim a 'figured identity'. Holland et al. describe this in their own empirical work on a university campus:

They were gaining a sense of their position vis-à-vis others, noting their relative lack of privilege and power. They were developing relational identities along with the figured identities. (1998, p.220) 
An exploration of 'positional identity' is a useful tool in contemporary society where there is considerable inequality, which impacts on graduate outcomes, as well as individual confidence to enter certain career fields. Inequalities are a preoccupation of sociological writing as well as policymakers (Bathmaker et al., 2016; Social Mobility Commission, 2019).

In using the construct 'space of authoring', Figured Worlds seeks to illuminate how individuals construct meaning dialogically around their 'figured' and 'positional identities'. In so doing, individuals draw upon different 'voices' and 'narratives' about careers and may begin to orchestrate these critically. We go on to present exemplars of the 'self-authoring' (p.170) of two research participants, both of whom are young women from working-class backgrounds who graduated (2014) from the same mid-ranking university in northern England. Methods in the study blended semi-structured interviews and a biographical approach. They contrast in terms of subject studied (i.e., Accountancy and Performing Arts), as well as ethnicity (British Asian and Mixed). Their disciplines of study contrast in imagined ideas of being a graduate. Performing Arts subjects do not tend to promise normative possibilities of career success, whereas Accountancy offers clearer structured career pathways. The exemplars serve to bring alive the individual subjectivities that these young women engage with as they find their way in the world.

\section{Applying theoretical tools}

\section{The Performing Arts graduate}

Sophia is a Performing Arts graduate and can be observed explicitly comparing herself to notions of how a graduate of her subject might be viewed, as well as how this contests with wanting to call herself an actor, which is what she desires to become. At the time of participation in the project, she had graduated about eighteen months previously and had recently moved to France for a two year programme at an Acting school, uneasily making use of an inheritance from her late father. 
Her 'self-authoring' is dialogic (Holland et al., 1998, p.170) as she articulates her own story to the researcher but also with an eye on how the multitude of characters within society may view her. She navigates different 'figured worlds' (p.41) as she tells her story, from that of being a successful undergraduate, to being an unemployed actor, to moving to France to study acting. Hope and expectancy underpin how she talks about herself and she draws upon emblematic 'narratives' (and narrativised characters within these) (p.53) in explaining her positioning. She clearly reflects upon how society-at-large may position her as a Performing Arts graduate and answers (and resists) this with evocative language that traces her dialogic engagement with making sense of who she is. For her, having a degree has been about her creative development as a performer. She feels that societyat-large positions Performing Arts degrees negatively and she defends her degree, framing this politically by commenting on government policy.

Leaving university with a Performing Arts degree can sometimes feel like you shouldn't have done it at all. It's very difficult to shake off the stereotype of being this showbiz, jazz hands, tokenistic, high energy team member. It can be demeaning at times: 'oh, you did performing arts, can I have a latte please'. I bet no one said that to Rik Mayall or Alan Rickman when they were studying. Performing Arts degrees have a bad rep for being doss degrees, and, of course, this stems from the governments lack of interest in Arts and Culture. Overall I've learnt a lot from being at university, academically and personally (cliche I know).

Her view of her degree is coloured by the labour market reality that a degree is not necessary to become an actor. When asked about her career goals, she seeks clarification of what is meant by career, and whether acting is counted as a 'normal career' or 'something you just do'. The 'figure' of an actor has a strong pull for her, but it is a precarious 'figure' that she cannot claim just because she is a graduate in a suitable subject: 'I'm sort of determined to prove that I am worthy to be an actor'. Being a Performing Arts graduate and doing her degree in the face of detractors (notably she recounts how her late father dismissed her ambitions) is evidence of this personal commitment and sacrifice to become an actor. She believes that in France, there is a more positive attitude to being an actor and the 
education associated with this, which is good for her own self-worth: 'being in the arts is very very highly regarded, not like it is in the UK where it's just you work unpaid for as long as possible.'

Her experience at the Acting school promises to be a transformative one and in telling this story she describes the leader of the school symbolically in heroic terms. She is 'mesmerised' by the experience and her commitment to the school is a sign of her commitment to be a 'worthy' actor. She chose the school over 'big dreams in London' of studying an MA at a specialist Drama school. For her 'acting is my life'.

He [the school's lead teacher] will strip you down ....and then he's able to sort of push you in the right direction to show your beauty as an actor...I'm having this sort of emotional sort of existential change, I'm still really in the same place as I was financially possibly, you know a year and a half ago... another twenty something year old cliché, which is what we all are.

Being a performer appears to have been a therapeutic experience for her; drama was the only thing she liked at school and eventually excelled. Her attitude to her current programme of study follows in this tradition and she invests considerable hope in the school's lead teacher, whose methods are extremely tough. She talks about a low period soon after she graduated when she felt adrift. During this time, she describes her clichéd experience of an actor signing on the dole to the bewilderment of Job Centre staff. Pragmatic concerns continue to lurk behind her idealism about her acting career.

In her authoring of self, it is possible to observe 'heteroglossia' (Holland et al, 1998, p.170) as she switches 'narratives' and 'voices'/discourses, e.g., Sophia's story shifts between adversity (relationship with family and school), and mobility (both geographically and personally) as she traces her path to becoming a 'worthy' actor. Interestingly, her use of these 'narratives' reflects her selfactualisation and transformation as she describes her experience at the French acting school which contrasts with conventional career advancement. In so doing, she captures a more idealistic 'voice' (Christie, 2019), one that evokes a values-based orientation and a subjective measure of success (Hall, 2004). We observe that by using the tool of 'heteroglossia', it is also possible to explore the tensions and contradictions in her story, e.g., the juxtaposed and narrativised 'father figures' of the father she 
rebelled against (and guiltily used an inheritance from) compared to her teacher who she eulogises. It is possible to see glimmers of what Holland et al. (1998) call 'world making' (p.272) in how Sophia orchestrates these 'voices' and 'narratives' in order to develop her identity as a 'worthy actor' in 'newly imagined communities' which are far from her original family roots in an English town.

\section{The Accountancy graduate}

Our second exemplar is from Farzana who also participated in the research eighteen months after graduation. She took a four-year sandwich degree in Accounting and Finance with a placement in the third year. At the time of the interview, she was working as a trainee accountant and studying for the final stage of professional accounting exams. Like Sophia, she moves between different 'figured worlds' (Holland et al., 1998, p.41) including that of being a successful undergraduate, a trainee accountant as well as that of her family context. She also draws upon mobility and adversity as 'narratives' (p.53) though in distinctly different ways to Sophia.

Although on a path that could be considered traditional in terms of a graduate career, i.e., with the scope for structured career advancement, Farzana reflects upon challenging experiences along the way. These depict her choices as illustrating her independence and her desire to break certain gender stereotypes. She describes a growing belief in her ability drawn from experiences at university such as being a student ambassador, to the discomfort of moving into professional accountancy. She balances this independence with a strong connection and loyalty to family, who are presented as important supporters and challengers. As such, she searches for her own subjective sense of identity across different 'figured worlds' and orchestrates different 'voices' (Holland et al, 1998, p.170) as she manages her desire to become a professional accountant while remaining a dutiful daughter.

Farzana recounts dialogically (Holland et al., 1998, p.170) an early experience that stimulated her to explore accountancy. She describes a careers talk given at her all-girl's secondary school by the 'college careers guy', the content of which her form tutor clearly disagreed with. 
...he was literally telling us about nursing careers, midwifery careers..., so quite a bit of a stereotype going on... and our tutor at the time was like, 'hey you know, ... cut everything that the college guy said, cos you girls, it doesn't mean you've got to limit yourself to those sorts of careers. You can go into business, you know, accounting and then her exact words were, well if you want to be an astronaut tomorrow then go out and be it'.

This incident in which Farzana became aware of contrasting perspectives upon what women's careers should be, leads her to be more determined to build her own career in a non-stereotyped way. Arguably, in the 'figured world' of an all-girls school, there may well be a greater attunement to oldfashioned though still-enduring stereotypes of female careers, although notably the form tutor also expresses their own bias in terms of idealised suitable careers for more academic girls. Farzana has responded to the idealism of her tutor though picking a more realistic career path (accountant rather than astronaut), but during the course of her interview does present an idealistic 'voice' (Christie, 2019) of someone who is highly motivated in her occupation. This 'voice' may contradict clichéd notions of careers in accountancy being a pragmatic and lucrative choice for many.

Farzana utilises both mobility and adversity 'narratives' (Holland et al., p.53) as she depicts her quest to become a chartered accountant. This requires her to develop the resources to imagine herself as one. This potential grows through her successful university career, though she also reflects on the adjustment from university to work environments. Although manifest differently to Sophia, Farzana also employs the 'narrative' of adversity when describing the 'sacrifice' she needs to make to qualify as an accountant, requiring considerable study for exams outside her working hours. The 'figure' (p.51) of a chartered accountant has a powerful draw for her.

...my long-term aim was to be a professional chartered accountant...So yeh, you sacrifice your weekends, which has been the hard part, but it has to be worth it. It's a short term sacrifice for the long gain, ...it's just determination and patience as well, cos I did fail one of them (exams) in between and I had to retake it and I passed it, so it's picking myself up and having the courage to take on such a hard task... 
This adversity 'narrative' of bouncing back from failure is associated with neoliberal ideas about grit and resilience (Burke and Scurry, 2019). Farzana is putting her own spin on this and 'self-authoring' (Holland et al, 1998, p.170), with an implication that she is making sense of the tensions between failure and quitting, together with the importance of using her support network in keeping going.

Farzana presents as aware of how her identity must change in order to be seen as a nascent finance professional. She recounts the significance of important mentors and senior colleagues as role models. These individuals do not have the heroic depiction that Sophia presents, however, they appear as valuable gatekeepers for her. In fostering these relationships which can give her the insider knowledge that her family cannot, she demonstrates a tactical 'voice' (Christie, 2019) in relation to employability, enacting the development of useful networks.

...I like sort of talking to people that have 'been there done that' sort of thing and I do gain quite a lot of insight into their careers ...I do like to sort of, maintain those kind of relationships. I've got a lot from it. They do kind of push me on quite a lot and that's the reason why I'm working so hard as I am today.

Notably, Farzana positions her family as a significant influence upon her and giving her the support and motivation she craves. She articulates her 'family mantra' that education is pivotal to occupational and social mobility. She expresses considerable loyalty and obligation to her family having lived at home throughout university and beyond, with no desire to live independently from them. As the youngest of six sisters, she considers family as important to her in paving the way for female independence.

...my father sort of pushes us into education, you know has that sort of mantra that without education you won't really go far... I am a family sort of girl and I didn't really want to move out, they [parents] didn't get to go to university so that's why we sort of appreciate the fact that we've got the opportunity and that's why as I say, we've all pushed on so much...

She talks about saving for a deposit on a house and moving in with her partner in the near future, indicating that she is ready for financial and domestic independence. Her negotiation of her 
'positionality' as a young woman (managing social and familial expectations) alongside a figuring of her identity as a graduate and professional accountant illustrate a weaving of 'positional' and 'figured identities' (Holland et al., p.220).

Farzana's story has firmly contradicted stereotypes of what someone like her should do while also fulfilling familial obligations. Although she is in what is deemed a very traditional graduate career, her story of reaching this position is not an ordinary one. Mobility and adversity 'narratives' underpin her story. She draws upon an idealistic 'voice' in which she claims a career in which she can harness her skills and knowledge fully, while also expressing a tactical 'voice' through which she has carefully employed additional resources, networks and sacrifices in order to get ahead. Like Sophia, in her heteroglossic orchestration of voices and narratives (Holland et al., 1998, p.170), we can observe glimmers of her own 'world-making' (p. 272) as she develops her own identity.

\section{Critical reflection on theory and methodology}

To facilitate a deep exploration and gain rich insights into 'identity in practice' (Holland et al., 1998, p.271), Figured Worlds broadly adopts a narrative and textual analytical approach. Ethnographic, narrative, and biographical approaches are often utilised depending on the research focus and context. A key aspect of Figured Worlds is the relationship between its four constructs and how an analytical focus on different constructs can facilitate methodological choice in ways that can best illuminate and explore 'identity in practice'. Holland et al. (1998) use data collected from different methods to explore each of the four constructs in-depth as they build towards the importance of each construct when understanding 'identity in practice'. Hence, a range of qualitative methods could be employed singularly or in tandem in Figured Worlds research, such as: participant observation; interviews; stories, biographies and autobiographies; conversations and focus groups; journals and diaries; digital media; songs, poetry, video/film. However, some methods may be more appropriate in certain contexts than in others, such as observation when exploring children's identities through play (Barron, 2014) or cultural rituals, dress and the use of artefacts and symbols (Holland et al., 1998), or interviews in life history approaches (Creaby, 2016; Solomon, 2012). 
Our interest in student and graduate 'voice' influenced our choice to work with in-depth interviews as the most useful tool in allowing for a detailed exploration of dialogical tensions each participant experienced via analysis of the 'space of authoring' construct. Indeed, the potential for making sense of single stories is a strength of a Figured Worlds approach due to the richness this can bring to exploring identity in context and thus also influenced our participant numbers. Although the focus on individual cases can be problematic in generating recommendations for policy-makers, we argue that a focus on individual subjectivities is useful in highlighting complexity and that there are no 'one size fits all' recommendations to emerge from our analysis. However, it is striking to observe commonality in the deep personal engagement of both Sophia and Farzana in consideration of their careers. This reflects dominant individualistic discourses, which lead individuals to measure their own worth as people in whether they are successful or not. However, in both cases their orchestrations of different 'voices' and 'narratives' gives them scope to begin to evaluate such norms. We conclude that profound insights can be gained from individual cases, so that it is not necessary to become preoccupied with the unit of analysis when engaging with Figured Worlds.

In considering the challenges we faced in bridging the theory-method relationship, we reflect that Figured Worlds is a valuable and rich, yet complex framework. Underpinned by a social constructionist ontology and requiring a thorough understanding of sociocultural perspectives, philosophical issues are integral to the research process as they constitute what researchers silently think about research (Scott and Usher, 2010). As Braathe and Solomon (2014) and Creaby (2016) argue, a researcher's own position, bias, assumptions and subjectivities, along with matters of trustworthiness and multi-vocality are important considerations in Figured Worlds research. In conducting analysis in this research project, an exploration of researcher 'positionality' as a careers professional at the participants' university and thus an 'insider' researcher (Mercer, 2007) was helpful in being alert to the nuances of power, position and privilege within the higher education context. A consideration of the researcher's own role (with multiple identities as careers adviser, educator, scholar) in the dialogic social construction of participants' realities served to facilitate a deeper and more nuanced understanding. 
We also recognise how using a Figured Worlds lens encourages academic knowledge exchange, which led us in writing this chapter together towards richer insights into our own understanding of student and graduate identities, as well as of each other as colleagues, which is important to us as higher education practitioners. Indeed, we argue that Figured Worlds requires reflexivity and is helpful in enriching practitioner understanding of the student experience. Thus, we feel that a researcher must anticipate the various nuances and challenges that are involved in engaging with a Figured Worlds lens, especially in practitioner inquiry and matters that relate to one's own professional identity.

In conclusion, we argue that Figured Worlds offers a valuable lens through which to explore the multiplicity of student and graduate identities and illuminate the space for possibility and agency. It can help to go beyond the dominant ways in which 'Student Voice' and 'Graduate Outcomes' are constructed and facilitate a deeper understanding of student and graduate journeys and our own roles as educators within learning communities.

\section{References}

Archer, M. S. (2007). Making our Way through the World. Cambridge: Cambridge University Press. Augar, P. (2019). Independent panel report to the Review of Post-18 Education and Funding: DfE, UK Government.

Bakhtin, M. (1981). The dialogic imagination: four essays. Austin: University of Texas Press. Bakhtin, M. (1986). Speech genres and other late essays (1st ed.). Austin: University of Texas Press.

Barrie, S. C. (2012). A research-based approach to generic graduate attributes policy. Higher Education Research and Development, 31(1), 79-92.

Barron, I. (2014). Finding a voice: A figured worlds approach to theorising young children's identities. Journal of Early Childhood Research, 12(3), 251-263.

Bathmaker, A.-M., Ingram, N. A., Abrahams, J., Hoare, T., Waller, R., and Bradley, H. (2016). Higher education, social class and social mobility: the degree generation: Palgrave Macmillan.

Bennett, D., Solomon, Y., Bergin, C., Horgan, M., and Dornan, T. (2017). Possibility and agency in Figured Worlds: becoming a 'good doctor'. Medical education, 51(3), 248-257.

Bissett, A. (2011). Pack Men: Hachette Scotland.

Blumer, H. (1986). Symbolic interactionism: perspective and method. Berkeley; London: University of California Press. 
Bourdieu, P. (1977a). Outline of a Theory of Practice (Vol. 16): Cambridge University Press.

Bourdieu, P. (1977b). Reproduction in education, society and culture. London; Beverly Hills: Sage.

Braathe, H. J., and Solomon, Y. (2014). Choosing mathematics: the narrative of the self as a site of agency. Educational Studies in Mathematics, 89(2), 151-166.

Brooks, R., and Waters, J. (2017). Materialities and mobilities in education: Routledge.

Burke, C., and Scurry, T. (2019). Graduate Resilience: A review of the literature and future research agenda. SRHE. Available online: https://www.srhe.ac.uk/downloads/reports-2017/CBurke-TScurrySRHE-Research-Report.pdf (accessed 23 September 2019)

Choudry, S., and Williams, J. (2016). Figured Worlds in the Field of Power. Mind, Culture, and Activity, 24(3), 247-257.

Christie, F. (2018). Constructing early graduate careers: navigating uncertainty in transition. (PhD). Lancaster University.

Christie, F. (2019). Competing Voices: a Figured Worlds approach to theorising graduate perspectives on career success. International Studies in Sociology of Education. 28 (3-4), 326-344.

CIPD. (2015). Over-qualification and skills mismatch in the graduate labour market. CIPD. Available online: www.cipd.co.uk/Images/over-qualification-and-skills-mismatch-graduate-labour-

market tcm18-10231.pdf (accessed 23 September 2019).

Creaby, F. (2016). Identity in Practice: A sociocultural exploration of leadership learning and development. (EdD). MMU.

D'Alessandro, D. (2008). Career Warfare: 10 Rules for Building a Sucessful Personal Brand on the Business Battlefield: McGraw Hill Professional.

Dacre Pool, L., and Sewell, P. (2007). The key to employability: developing a practical model of graduate employability. Education + Training, 49(4), 277-289.

Duckworth, A. (2016). Grit: The power of passion and perseverance: Simon and Schuster.

Elias, P., and Purcell, K. (2013). Classifying graduate occupations for the knowledge society.

Futuretrack Working Paper No. 5. IER. Available online:

www2.warwick.ac.uk/fac/soc/ier/futuretrack/findings/elias_purcell_soche_final.pdf (accessed 23

September 2019)

Finn, K. (2015). Personal Life, Young Women and Higher Education: A Relational Approach to Student and Graduate Experiences: Palgrave Macmillan UK: London.

The Graduate (1967), [Film] Dir. Nichols, M. USA. Turnam Productions.

Hall, D. T. (2004). The protean career: A quarter-century journey. Journal of vocational behavior, $65(1), 1-13$.

HESA. (2016). Consultation on principles and future requirements for the UK's public interest data about graduates. Cheltenham: HESA. Available online:

https://www.hesa.ac.uk/innovation/records/reviews/newdlhe/consultation (accessed 23 September 2019)

Holland, D., Lachicotte, W., Skinner, D., and Cain, C. (1998). Identity and agency in cultural worlds. Cambridge, Mass.: Harvard University Press.

Holland, D., and Lave, J. (2019). Social Practice Theory and the Historical Production of Persons. In Cultural-Historical Approaches to Studying Learning and Development (pp. 235-248): Springer. 
Holland, D., and Lave, J. (Eds.). (2001). History in person: enduring struggles, contentious practice, intimate identities (1st ed.). Santa Fe, Oxford: School of American Research Press, James Currey.

Holmes, L. (2015). Becoming a graduate: The warranting of an emergent identity. Education and Training, 57(2), 219-238.

Ingram, N., and Abrahams, J. (2015). Stepping outside of oneself: How a cleft-habitus can lead to greater reflexivity through occupying "the third space". In J. Thatcher, N. Ingram, C. Burke, and J. Abrahams (Eds.), Bourdieu: The Next Generation: The Development of Bourdieu's Intellectual Heritage in Contemporary UK Sociology (pp. 140-156): Routledge.

Killeen, C. (2015). In Real Life: Canongate Books.

Leont'ev, A. N. (1978). Activity, consciousness, and personality: Prentice Hall.

Loveday, V. (2015). Working-class participation, middle-class aspiration? Value, upward mobility and symbolic indebtedness in higher education. The Sociological Review, 63(3), 570-588.

Mead, G. H. (1934). Mind, self and society (Vol. 111): Chicago University of Chicago Press.

Mercer, J. (2007). The challenges of insider research in educational institutions: Wielding a doubleedged sword and resolving delicate dilemmas. Oxford Review of Education, 33(1), 1-17.

Moreau, M. p., \& Leathwood, C. (2006). Graduates and employment and the discourse of employability: a critical analysis. Journal of Education and Work, 19(4), 305-324.

Pryor, R., and Bright, J. (2008). Archetypal narratives in career counselling: a chaos theory application. International Journal Educational Vocational Guidance, 8(2), 71-82.

Scott, D., and Usher, R. (2010). Researching education: Data, methods and theory in educational enquiry: Bloomsbury Publishing.

Social Mobility Commission. (2019). State of the Nation 2018-19: Social Mobility in Great Britain. UK Government

Solomon, Y. (2012). Finding a Voice? Narrating the Female Self in Mathematics. Educational Studies in Mathematics, 80(1-2), 171-183.

Standing, G. (2014). The precariat: The new dangerous class. London, New York: Bloomsbury Academic.

Tholen, G. (2014). The Changing Nature of the Graduate Labour Market: Media, Policy and Political Discourses in the UK: Springer.

Tomlinson, M. (2014). Exploring the impact of policy changes on students' attitudes and approaches to learning in higher education. HEA. Available online:

https://www.heacademy.ac.uk/system/files/resources/exploring the impact of policy_changes_stude nt experience.pdf (accessed 23 September 2019)

Vygotsky, L. S. (1978). Mind in society: The development of higher mental process. In: Cambridge, MA: Harvard University Press.

Vygotsky, L. S. (1986). Thought and language (rev. ed.). In: Cambridge, MA: MIT Press.

West, K. (2004). The College Dropout [Album]. USA: Def Jam Recordings.

Yorke, M. (2006). Employability in higher education: what it is and what it is not. York: HEA. 